\title{
Penggunaan Digital Guerilla Marketing Dalam Usaha Kecil Dan Menengah
}

Siti Ayu Nur Fadhila

Program Studi Manajemen Fakultas Ekonomi dan Bisnis

Universitas Trunojoyo Madura

\begin{tabular}{|c|c|c|}
\hline \\
\hline INFO ARTIKEL & \multicolumn{2}{|c|}{ Abstract } \\
\hline \multicolumn{3}{|l|}{$\begin{array}{l}\text { Sejarah Artikel: } \\
\text { Diterima : } \\
\text { Diperbaiki : } \\
\text { Disetujui } \\
\text { Keywords: }\end{array}$} \\
\hline & \multicolumn{2}{|c|}{ Abstraks } \\
\hline $\begin{array}{l}\text { Kata Kunci: } \\
\text { Strategi pemasaran, guerilla } \\
\text { marketing, digital marketing, } \\
\text { UMKM. } \\
\text { DOI: }\end{array}$ & \multicolumn{2}{|c|}{$\begin{array}{l}\text { Penelitian ini bertujuan untuk mengetahui (1) Prinsip dari strategi } \\
\text { guerilla marketing dan (2) Penerapan strategi guerilla marketing } \\
\text { dalam konsep digital marketing bagi Usaha Kecil dan Menengah } \\
\text { (UKM). Jenis penelitian ini merupakan penelitian kualitatif dengan } \\
\text { teknik pengumpulan data mengunakan studi literatur. Hasil } \\
\text { penelitian menunjukkan, (1) terdapat } 3 \text { prinsip strategi guerilla } \\
\text { marketing yatitu surprise effect, diffusion effect, dan low cost effect (2) } \\
\text { penerapan strategi guerilla marketing dalam konsep digital marketing } \\
\text { dapat dilakukan dengan cara penukaran poin belanja, } \\
\text { menampilkan kuis, dan menjangkau konsumen dengan } \\
\text { menampilkan testimoni secara suka rela dari konsumen yang merasa } \\
\text { puas. }\end{array}$} \\
\hline \multicolumn{2}{|c|}{$\begin{array}{l}\text { Koresponsi: } \\
\text { Nama: Siti Ayu Nur Fadhila } \\
\text { Email: sitiayu@gmail.com, p-ISSN: 2355-9543 } \\
\text { email sitiayu@gmail.com }\end{array}$} & $\begin{array}{l}\text { ISSN: } \\
\text { 2355-9543(Print) } \\
\text { ISSN: 2460-3775 } \\
\text { (on-line) }\end{array}$ \\
\hline
\end{tabular}

\section{PENDAHULUAN}

Usaha Kecil dan Menengah (UKM) merupakan salah satu bidang yang

memberikan kontribusi yang signifikan dalam memacu pertumbuhan ekonomi Indonesia. Usaha Kecil dan Menengah memiliki posisi penting, bukan saja dalam penyerapan tenaga kerja dan kesejahteraan masyarakat di daerah, dalam banyak hal Usaha Kecil dan Menengah (UKM) menjadi perekat dan menstabilkan masalah kesenjangan sosial. Hal ini dikarenakan daya serap Usaha Kecil dan Menengah (UKM) terhadap tenaga kerja yang sangat besar dan dekat dengan rakyat kecil. Banyak kalangan yang berpandangan bahwa usaha kecil merupakan tumpuan dan harapan masa mendatang pembangunan nasional. Hal ini dapat dilihat pada saat keadaan krisis yang berkepanjangan, tampaknya usaha kecil dapat tetap mampu bertahan. Namun, disamping itu unit usaha ini seringkali terabaikan hanya karena hasil produksinya dalam skala kecil dan belum mampu bersaing dengan unit usaha lainnya.

Salah satu permasalahan yang dihadapi oleh Usaha Kecil dan Menengah (UKM) adalah pemasaran (Hafsah, 2004; Kuncoro, 2008; 


\section{Penggunaan Digital Guerilla Marketing,.. Siti Ayu Nur Fadhila}

Kurniawan, 2009; Supardi, 2009). Pemasaran dengan metode konvensional memerlukan biaya tinggi, misalnya membuka cabang baru, ikut pameran, pembuatan dan penyebaran brosur dan sebagainya. Berkembangnya internet menjadi sarana yang efisien untuk membuka jalur pemasaran model baru bagi produk Usaha Kecil dan Menengah (UKM). Di samping biayanya relatif murah, dengan memanfaatkan internet penyebaran informasi akan lebih cepat dan jangkauannya lebih luas (Supardi, 2009). Dalam menghadapi persoalan tersebut maka Usaha Kecil dan Menengah (UKM) juga perlu merumuskan strategi dalam kegiatan pemasarannya. Salah satu strategi untuk memasarkan produk adalah guerrilla marketing. Guerrilla marketing menggunakan berbagai cara alternatif pemasaran yang paling efektif. Ketika sebuah perusahaan memilih untuk menggunakan guerrilla marketing, perusahaan tersebut berharap untuk mampu menjangkau konsumen di tempat-tempat yang tidak terduga. Guerrilla marketing merupakan suatu konsep strategi yang unik untuk dapat diterapkan oleh pelaku usaha tidak hanya saat penjualan mengalami kemerosotan tetapi juga dapat digunakan saat target penjualan mencapai titik yang maksimal. Guerrilla marketing yang diterapkan dengan konsep digital marketing akan menjadi alternatif tersendiri sebagai strategi pemasaran bagi pelaku usaha khususnya Usaha Kecil dan Menengah (UKM) dalam menciptakan sesuatu yang baru dan berbeda pada produknya yang nantinya akan memberikan prospek yang besar dalam meningkatkan penjualannya.

\section{TINJAUAN PUSTAKA}

\section{Usaha Kecil dan Menengah}

Usaha Kecil dan Menengah (UKM) merupakan salah satu bagian penting

dari perekonomian suatu negara ataupun daerah, termasuk di Indonesia. Usaha Kecil dan Menengah (UKM) ini juga sangat berperan dalam penyerapan tenaga kerja dan sangat produktif dalam menghasilkan tenaga kerja baru dan juga dapat menambah jumlah unit usaha baru yang mendukung pendapatan rumah tangga dari Usaha Kecil dan Menengah (UKM) tersebut. Usaha Kecil dan Menengah (UKM) adalah sebuah istilah yang mengacu ke jenis usaha kecil yang memiliki kekayaan bersih paling banyak Rp 200.000.000 tidak termasuk tanah dan bangunan tempat usaha serta usaha yang berdiri sendiri.

Menurut Keputusan Presiden RI no. 99 tahun 1998 pengertian Usaha Kecil adalah: “Kegiatan ekonomi rakyat yang berskala kecil dengan bidang usaha yang secara mayoritas merupakan kegiatan usaha kecil dan perlu dilindungi untuk mencegah dari persaingan usaha yang tidak sehat." UKM atau UMKM (Usaha Mikro, Kecil, dan Menengah) menurut Undang-undang Republik Indonesia nomor 20 tahun 2008 tentang Usaha Mikro, Kecil, dan Menengah (UMKM) adalah suatu badan usaha yang memiliki kriteria sebagai berikut:

1. Usaha Mikro adalah usaha produktif milik orang perorangan atau badan usaha perorangan yang memenuhi kriteria-kriteria berikut: memiliki kekayaan bersih paling banyak Rp50.000.000,00 (lima puluh juta rupiah) tidak termasuk di dalamnya, tanah dan bangunan tempat usaha;

2. Usaha Kecil adalah usaha ekonomi produktif yang berdiri sendiri, yang dilakukan oleh orang perorangan atau bukan cabang perusahaan yang dimiliki, dikuasai, atau menjadi bagian baik langsung maupun tidak langsung dari Usaha Menengah atau Usaha Besar yang memenuhi kriteria berikut: memiliki kekayaan bersih minimum Rp51.000.000,- (lima puluh satu juta rupiah) sampai dengan Rp500.000.000,- (lima ratus juta rupiah) tidak termasuk tanah dan bangunan tempat usaha;

3. Usaha Menengah adalah usaha ekonomi produktif yang berdiri sendiri, yang dilakukan oleh orang perorangan atau badan usaha yang bukan merupakan anak perusahaan atau cabang perusahaan yang dimiliki, dikuasai, atau menjadi bagian baik langsung maupun tidak langsung dengan Usaha Kecil atau Usaha Besar dengan kriteria sebagai berikut: memiliki kekayaan bersih minimum Rp501.000.000.- (lima ratus juta rupiah) sampai dengan paling banyak Rp10.000.000.000,- (sepuluh milyar rupiah) tidak termasuk tanah dan bangunan tempat usaha.

\section{Pemasaran}

Pemasaran di definisikan sebagai sebuah proses kemasyarakatan dimana

individu dan kelompok memperoleh apa yang mereka butuhkan dan inginkan dengan menciptakan, menawarkan, dan secara bebas mempertukarkan produk dan jasa yang bernilai dengan orang lain (Philip kotler dan Kevin Lane 2009). American Marketing Association (AMA) dalam buku manajemen pemasaran,

2009 mendefinisikan bahwa Pemasaran adalah suatu fungsi organisasi dan serangkaian proses untuk menciptakan, mengkomunikasikan, dan memberikan nilai kepada pelanggan dan untuk mengelola hubungan pelanggan dengan cara yang 


\section{Jurnal Studi Manajemen dan Bisnis}

Vol. 5 (2) 2018

menguntungkan organisasi dan pemangku kepentingan. Inti dari pemasaran adalah mengidentifikasi dan memenuhi kebutuhan manusia dan sosial. Salah satu definisi singkat dari pemasaran adalah "memenuhi kebutuhan dengan cara yang menguntungkan". Selalu ada kebutuhan akan penjualan. Namun tujuan dari pemasaran adalah membuat penjualan berlimpah. Tujuan pemasaran adalah mengetahui dan memahami pelanggan dengan baik sehingga produk atau jasa bisa sesuai dengan kebutuhannya sehingga terjual sendiri. Idealnya, pemasaran harus menghasilkan seorang pelanggan yang siap untuk membeli. Untuk mencapai tujuan tersebut di perlukan adanya strategi pemasaran. Strategi pemasaran adalah logika pemasaran, dan berdasarkan itu, unit bisnis diharapkan untuk mencapai sasaransasaran pemasarannya. Menurut Hasan (2013), strategi pemasaran yang baik harus dibangun atas dasar pemahaman bisnis yang kuat, dikombinasikan dengan pemahaman kebutuhan dan keinginan pelanggan, pesaing dan skills, dan core bisnis termasuk dengan para pemasok dan distributor. Strategi pemasaran terdiri dari pengambilan keputusan tentang biaya pemasaran dari perusahaan, bauran pemasaran, dan alokasi pemasaran. Strategi pemasaran dapat dinyatakan sebagai dasar tindakan yang mengarah pada kegiatan atau usaha pemasaran, dari suatu perusahaan, dalam kondisi persaingan dan lingkungan yang selalu berubah agar dapat mencapai tujuan yang diharapkan. Strategi pemasaran adalah alat fundamental yang direncanakan untuk mencapai perusahaan dengan mengembangkan keunggulan bersaing yang berkesinambungan melalui pasar yang dimasuki dan program pemasaran yang digunakan untuk melayani pasar sasaran tersebut.

\section{Guerilla Digital Marketing}

Menurut Ridwan Sanjaya \& Josua Tarigan (2009), digital marketing ialah

kegiatan marketing termasuk branding yang menggunakan berbagai media berbasis web seperti blog, web site, e-mail, adwords, ataupun jejaring sosial. Tentu saja digital marketing bukan hanya berbicara tentang marketing internet. Menurut detik.com, online marketing pada dasarnya adalah kegiatan komunikasi pemasaran dengan menggunakan media internet. menurut Kotler (2002) internet marketing memiliki lima keuntungan besar bagi perusahaan yang menggunakannya. Pertama, baik perusahaan kecil maupun perusahaan besar dapat melakukannya. Kedua, tidak terdapat batas nyata dalam ruang beriklan jika dibandingkan dengan media cetak dan media penyiaran. Ketiga, akses dan pencarian keterangan sangat cepat. Keempat, situsnya dapat dikunjungi oleh siapapun, dimanapun di dalam dunia ini, kapanpun. Kelima, belanja dapat dilakukan secara lebih cepat dan sendirian. (Sarwono dan Prihartono:2012) mengemukakan bahwa teknik yang memudahkan akses dan publikasi informasi menggunakan interaksi social melalui social media.

Dari sudut pandang bisnis, sosial media adalah tentang memungkinkan pembicaraan. Sosial media juga tentang cara pembicaraan ini bisa dihasilkan, dipromosikan, dan dijadikan pendapatan (Safko, 2009). Media sosial adalah tempat, alat bantu, layanan yang memungkinkan individu untuk mengekspresikan diri mereka untuk bertemu dan berbagi dengan rekan lainnya melalui teknologi internet. Sosial media adalah fase perubahan bagaimana orang menemukan, membaca, berbicara, dan membagi-bagikan informasi, berita, data kepada orang lain. Sosial media menjadi sangat populer karena kemudahan dan memberikan kesempatan kepada orang-orang untuk dapat terhubung secara online dalam bentuk hubungan personal, politik dan kegiatan bisnis. Sosial media menyediakan layanan komunikasi sosial. Menurut Strauss dan Frost (2009), tujuh tahap dalam perancangan emarketing adalah Situation Analysis (Analisis Situasi), E- Marketing Strategic Planning (Strategi Perencanaan E-Marketing), Objectives (Tujuan), EMarketing Strategy (Strategi E- Marketing), Implementation Plan (Rencana Pelaksanaan), Budget (Anggaran), Evaluation Plan (Rencana Evaluasi).

Guerilla Marketing adalah strategi marketing yang banyak digunakan di marketing mix yaitu aspek promosi. Dengan banyaknya kegiatan promosi yang ada tentunya diperlukan suatu cara agar promosi dapat tampil beda dan menarik perhatian konsumen, oleh sebab itu diperlukan teknik yang inovatif, efektif serta efisien dalam hal biaya, hal inilah yang diutamakan oleh Guerilla Marketing dalam upaya memenangkan persaingan. Guerrilla Marketing tidak bergantung pada besarnya pengeluaran anggaran pemasaran, namun bergantung pada kreativitas dan imajinasi (Levinson, 2016:12). Teknik Guerrilla Marketing antara lain:

1) Word of Mouth (WoM)

Brown et al. (2005) dalam Harsasi (2006) mendefinisikan Word of Mouth sebagai informasi tentang suatu target objek yang dipindahkan dari 


\section{Penggunaan Digital Guerilla Marketing,.. Siti Ayu Nur Fadhila}

satu individu ke individu lain yang dilakukan secara langsung atau tidak langsung melalui media komunikasi.

2) Buzz Marketing

Buzz marketing telah menjadi cara yang sangat efektif karena individu merasa lebih mudah untuk percaya teman-teman dan keluarga daripada promosi biasa dari produk (Dye, 2012).

3) Viral Marketing

Viral marketing menciptakan efek berantai seperti WoM. Viral marketing mirip dengan WoM, perbedaannya adalah bahwa ketika seorang konsumen menjadi sadar akan kegiatan pemasaran viral, ia mengatakan kepada lima hingga sepuluh orang tentang hal itu dan kemudian mereka memberitahu lima sampai sepuluh orang, dan sebagainya. Rahasia jenis pemasaran ini adalah untuk menjangkau dan menyentuh titik gairah pelanggan yang akan menyebarkan informasi kepada orang lain (Ferguson, 2008; Caemmerer, 2009).

3) Ambient Marketing

Menurut Luxton and Drummond (2000:735), definisi ambient marketing adalah penempatan iklan di tempat yang tidak biasa dan tidak terduga (lokasi) sering dilakukan dengan metode konvensional (eksekusi) dan menjadi eksekusi iklan yang pertama atau hanya satu-satunya yang melakukannya (sementara).

4) Ambush Marketing

Definisi ambush marketing adalah bahwa perusahaan bertindak seperti mereka menjadi sponsor untuk sebuah acara, tetapi mereka sebenarnya tidak. Pada saat yang sama, mereka mendapatkan manfaat yang sama seolah-olah mereka adalah sponsor resmi. Dapat dikatakan, ambushers yang menghindari biaya sponsor, tapi pada saat yang sama mereka ingin menyesatkan pelanggan untuk membuat mereka percaya bahwa perusahaan tersebut menjadi sponsor (Mazodier, Quester, and Chandon, 2009

\section{PEMBAHASAN}

Gambaran Guerilla Marketing

Dari beberapa pengertian menurut para ahli, dapat di simpulkan bahwa

guerrilla marketing adalah sebuah strategi yang dibuat oleh sebuah perusahaan kegiatan tersebut untuk menciptakan memori jangka panjang tentang sebuah produk atau jasa. Menurut Halim (2012), guerrilla marketing menimbulkan beberapa efek yang dipengaruhi oleh 3 elemen yaitu:

1. Surprise Effect

Orang yang merasa terkejut akan menghentikan aktivitasnya untuk sementara waktu dan mengalihkan perhatiannya pada event yang sedang terjadi. Untuk merangsang masyarakat umum untuk berbagi dan meyebarkan pesan, iklan harus berisi kejutan yang memicu emosi, untuk dapat memotivasi orang untuk berbagi pengalaman mereka (Derbaix dan Vanham, 2003).

\section{Diffusion Effect}

Pemasaran gerilya memberikan kemungkinan untuk menjangkau sejumlah besar individu tanpa harus meningkatkan total biaya. Efek difusi yang disebut berhasil dicapai dengan biaya yang efisien dan berorientasi pada tujuan (Levinson dan Lautenslager, 2005).

\section{Low Cost Effect}

Menjelaskan bahwa iklan akan mengeluarkan biaya, tetapi pada saat yang sama dapat membuat tertarik ribuan orang. Pada akhirnya, saat biaya tersebut dibagi antara senua orang-orang ini, biaya per orang yang dicapai akan rendah (Hutter \& Hoffmann, 2011).

\section{Guerilla Marketing dalam Konsep Digital Marketing \\ Berdasarkan 3 elemen dalam guerilla marketing, penerapan yang dapat dilakukan \\ dengan konsep digital marketing dalam \\ Usaha Kecil dan Menengah (UKM) \\ adalah sebagai berikut: \\ 1. Surprise Effect \\ Unsur ini harus ada sehingga konsumen} merasa ada sesuatu yang mengejutkan perasaan. Pada dasarnya orang sesekali senang mendapat kejutan sehingga dia lebih ingin tahu tentang apa yang dilihatnya. Dalam media digital, ini dapat di terapkan dengan cara pengundian poin belanja yang dikemas dengan konsep volume pembelian dalam kurun waktu tertentu dimana poin yang di peroleh tersebut dapat di tukar dengan barang yang di inginkan.

\section{Diffusion Effect}

Dengan adanya media digital, diffusion effect yang dihasilkan bisa menjadi lebih cepat. Hal ini di sebabkan peran dari media digital yang mampu mempercepat penyebaran informasi antar medium dan lebih tersegmentsi. Dalam penggunaan media digital pelaku usaha dapat menampilkan beberapa kuis misalnya mengenai kesehatan atau mengenai psikologi seseorang dimana di dalam kuis tersebut mewajibkan konsumennya untuk melakukan syarat tertentu seperti merepost ulang, atau menyukai laman sebagai syarat untuk mendapatkan jawaban dari kuis tersebut. 


\section{Jurnal Studi Manajemen dan Bisnis}

Vol. 5 (2) 2018

\section{Low Cost Effect}

Semakin luas pelaku usaha bisa menjangkau customer, maka semakin tinggi juga kesempatan strategi promosi dengan budget minimal akan berhasil. Salah satu strategi promosi dengan budget minimal yang paling efektif adalah menjangkau customer baru berdasarkan testimoni atau referensi dari customer yang puas akan produk atau service yang di berikan. Customer yang puas akan memberikan testimoni atau referensi kepada orang lain dan ini amatlah efektif serta berbudget minimal.

\section{SIMPULAN DAN SARAN \\ Kesimpulan}

Berdasarkan hasil dan pembahasan diatas dapat disimpulkan bahwa

Guerilla Marketing dapat menjadi salah satu bentuk komunikasi pemasaran alternatif yang menarik di tengah semakin persaingan yang ketat antara para pelaku usaha. Dengan kemajuan teknologi, media digital memiliki peran penting dalam keberhasilan sebuah strategi guerilla marketing. Guerilla marketing yang di terapkan dalam konsep digital marketing memberikan pengaruh yang signifikan terhadap Surprise effect, diffusion effect, dan low cost yang dapat di aplikasikan dalam strategi pemasaran Usaha Kecil dan Menengah (UKM). Penggunaan strategi guerrilla marketing terbutki efektif dalam mendapatkan konsumen. Hal tersebut terjadi karena konsep dari guerrilla marketing yang unik sehingga sangat mudah untuk menarik perhatian konsumen.

\section{Saran}

Untuk penelitian selanjutnya diharapkan dapat melanjutkan dan

mengembangkan lagi penelitian dengan obyek dan sudut pandang yang berbeda misalnya perluasan masalah yang dikaji dan pemaparan teori yang lebih spesifik sehingga dapat memperkaya pengetahuan kajian dari penggunaan strategi guerilla digital marketing bagi Usaha Kecil dan Menengah ( UKM).

\section{DAFTAR PUSTAKA}

Abdul Halim dkk, 2012. Akuntansi Sektor Publik Akuntansi Keuangan Daerah.

Edisi 4. Penerbit Salemba Empat.

Hasan,Ali. 2013, Marketing, Cetakan Pertama, Media Pressdindo Yogyakarta. Hafsah, M.J. 2004. Upaya Pengembangan Usaha Kecil dan Menengah (UKM).

Jurnal Infokop Nomor 25. http:/ / kuisioner.lp2m.unpkediri.ac.id/index.p hp/manajemen/article/view/701, di akses pada tanggal 7 Juli 2018. http:/ / repository.ipb.ac.id/handle/123456789 /65571, di akses pada tanggal 7 Juli 2018.

http://www.hukumonline.com/, di akses pada tanggal 7 Juli 2018. https:/ / catatanmarketing.wordpress.com/tag /marketing-menurut-para-ahli/, di akses pada tanggal 7 Juli 2018. https://id.wikipedia.org/wiki/Strategi_pema saran, di akses pada tanggal 7 Juli

2018.

https://id.wikipedia.org/wiki/Usaha_Kecil_dan_ Menengah, di akses pada tanggal

8 Juli 2018.

Kotler, Philip \& Lane, kevin. 2009. Manajemen pemasaran.Jakarta:penerbit erlangga.

Kotler, Philip, 2002, Manajemen Pemasaran, Jilid 1, Edisi Milenium, Jakarta. Kuncoro, Mudrajad, 2008. Tujuh Tantangan UKM di Tengah Krisis Global.

Harian Bisnis Indonesia 21 Oktober 2008. [Online]

http://www.mudrajad.com/upload/Tujuh\%20 Tantangan $\%$

20UKM\%20di\%20Tengah\%20Krisis\%20Global.pdf Diakses tanggal 5

Juli 2018.

Kurniawan, Didi. 2009. Mengembangkan Ekonomi Kerakyatan dengan Akselerasi Sektor Riil dan UKM. Tersedia [Online] http:/ / didikurniawan.web.id/2009/04/29/ mengembangkan-ekonomi- kerakyatandengan-akselerasi-sektor-riil-dan-ukm/

Diakses tanggal 6 Juli

2018.

Safko, Lon \& David K. Brake. 2009. The Social Media Bible. New Jersey. Sanjaya, Ridwan dan Josua Tarigan, 2009. Creative Digital Marketing. PT Elex.

Media Komputindo.

Sarwono, Jonathan \& K Prihartono, A. H. (2012). Perdagangan Online: Cara.

Bisnis di Internet. Jakarta: PT Elex Media Komputindo.

Strauss \& Frost, 2011, E-Marketing, Sixth Edition, Pearson: New Jersey.

Supardi, Julian. 2009. Rancang Bangun Collaborative System Pemasaran Hotel Secara online dengan Pendekatan Mediator based. Jurnal Sistem Informasi Fasilkom Unsri Vol 1 No 2. 
JSMB Vol. 5 (2) 2018 hlm. 95-100 Jurnal Studi Manajemen dan Bisnis http://journal.trunojoyo.ac.id/jsmb 